\title{
Penyelesaian Sengketa Bisnis Keuangan Islam Melalui Pengadilan Di Malaysia Dan Relevansinya Dengan Indonesia
}

\author{
Agus Triyanta \& Rusni Hassan \\ Dosen FH UII Yogyakarta \& assistant professor pada Ahmad \\ Ibrahin Kulliyyah of Laws International Islamic University \\ Malaysia \\ e-mail:a-triyanta@fh.uii.ac.id
}

\begin{abstract}
Islamic financial transactions, particularly in Islamic banking business, is a new mode of financial transaction in the nomenclature of the law of contracts. Different from conventional financial transactions which have been established for a long time, Islamic financial transaction is a newly introduced and is still evolving to find out its ideal form. Having said this, dispute settlement for cases arising from the Islamic financial transactions certainly need sufficient attention from the judicial authority in Indonesia. If for about fiveteen years dispute settlement in this matter was under the authority of the Shariah Arbitration Panel (Basyarnas), today, this dispute settlement can be brought to the court of juctice. It is made possible by virtue of the issuance of the Act no. 3 of 2006 on Religious Court and also the approval of the bill of Shariah Banking Act by the members of parliament. This fact suggests that for Indonesia necessary preparations pertinent to the court sistems to be rady in hadling the cases are strongly demanded. In this situation, Malaysia's experiences in matters pertinent to dispute settlement of Islamic financial business through the court is a good case to be learned.
\end{abstract}

Keywords: Sengketa Bisnis, Keuangan Islam, pengadilan Malaysia

\section{Pendahuluan}

Malaysia dan Indonesia adalah dua negara di Asia Tenggara dengan mayoritas penduduknya memeluk agama Islam. Kedua negara ini merupakan tempat yang oleh banyak pengamat dilihat sebagai kawasan yang memungkinkan bisnis keuangan Islam (Islamic financial business) berkembang dengan baik. Malaysia sebagai negara yang memulai bisnis keuangan Islam sangat awal dibanding berbagai negara lain di kawasan ini,ialah sejak tahun 1983 dengan didirikannya Bank Islam Malaysia 
Berhard (BIMB). Malaysia hari ini telah diakui sebagai salah satu hub (pusat) pengembangan bisnis dimaksud. Ada 12 bank Islam (full fledge) dan 17 perbankan konvensional yang membuka layanan keuangan dengan prinsip syariah beroperasi di Malaysia, terdiri dari perbankan nasional dan internasional. ${ }^{1}$

Indonesia memulai bisnis ini sekitar satu dekade lebih akhir dari Malaysia. Meski perkembangan yang dicapai oleh bisnis keuangan yang berdasarkan prinsip syariah di Indonesia tidak sebesar dari perkembangan bisnis sejenis di negara Malaysia, namun hari ini industri keuangan syariah telah menunjukkan realita yang cukup baik. Ada 3 bank yang beoperasi secara penuh dengan menggunakan prinsip syariah, dan sisanya, ada 28 bank konvensional yang membuka layanan perbankan syariah. Jumlah tersebut masih ditambah dengan jumlah Bank Perkreditan Rakyat Syariah (BPRS) yang hari ini telah mencapai jumlah tidak kurang dari 105buah. ${ }^{2}$

Atas dasar telah matangnya usia perbankan Islam di Malaysia sebagaimana nampak dari ilustrasi di atas, Malaysia diasumsikan telah memiliki pengalaman yang relatif utuh tentang penyelesaian kasus-kasus sengketa bisnis keuangan Islam. Sudah barang tentu, dari berbagai jenis kasus-kasus yang muncul dan telah diselesaikan, memberikan kontribusi bagi perkembangan perangkat hukum dan juga sekaligus mewarnai perkembangan dari bisnis keuangan Islam di negeri tersebut. Lebih dari itu, bagaimana cara dan seberapa efektif dan efisiennya kasus-kasus diselesaikan juga dapat memberikan suatu keuntungan yang berupa public confidence, ialah kepercayaan lembaga keuangan di hadapan masyarakat. Hal ini pada gilirannya akan memberikan leverage bagi imej bisnis keuangan Islam di sebuah negara. Dalam konteks seperti inilah, melihat pengalaman Malaysia menjadi urgen, utamanya bagi Indonesia yang sedang dalam tahapan elementer dalam memasuki era penyelesaian sengketa bisnis melalui pengadilan, setelah dalam satu dekade lebih mempercayakan penyelesaiannya hanya pada proses arbitrase syariah.

${ }^{1}$ Data per Januari 2008, pada "List of Financial Institutions Offering Islamic Banking Services," diakses dari http//:www.bnm.gov.my, 16 Juli 2008.

${ }^{2}$ Data per Mei 2008, lihat pada "Statistik Perbankan Syariah (Islamic Banking Statistics)," diakses dari http//:www.bi.go.id, pada 16 Juli 2008. 


\section{Perkembangan Bisnis Keuangan Islam di Malaysia dan Perangkat Hukumnya}

Sejak awal kehadirannya bisnis keuangan Islam di Malaysia, dalam hal ini dirintis dengan pendirian BIMB, telah difasilitasi dengan berbagai kebijakan pemerintah yang menjadi insentif bagi pengembangan bisnis keuangan Islam. BIMB, bank Islam pertama, berdiri dengan mendasarkan diri pada Islamic Banking Act 1983 (IBA). ${ }^{3}$ Undang-undang ini secara spesifik hanya mengatur bank yang sepenuhnya beroperasi dengan prinsip syariah. Sedangkan bagi bank konvensional yang membuka layanan syariah, atau yang sering disebut dengan syariah window, diatur dengan undang-undang yang lain, ialah Banking and Financial Institutions Act 1989 (BAFIA).

Di samping kedua perangkat hukum tersebut, perbankan Islam tidak bisa dilepaskan keterkaitannya dengan berbagai atauran hukum yang lain. Bisnis keuangan Islam terkait juga dengan aturan hukum yang berlaku secara general, misalnya Contract Act, National Land Code, Companies Act, Hire Purchase Act, Rules of High Court, dan sebagainya. Di samping itu, ada aturan hukum yang cukup berpengaruh terhadap bisnis keuangan Islam yaitu, hukum perpajakan, yang meliputi: Real Property Gain Tax Act 1976 serta Stamp Act 1949.

Berbagai undang-undang tersebut saling terkait antar satu dengan lainnya, dan kesemuanya mempengaruhi transaksi keuangan Islam. Hal ini berpengaruh pada problem di seputar apakah perbankan Islam menggunakan "true transactions" ialah transaksi yang sebenarnya dan sesuai dengan prinsip syariah ataukah lebih merupakan "national transactions" atau transaksi yang lebih tunduk pada ketentuan hukum nasional dari pada prinsip syariah. Juga, apakah transaksi-transaksi tertentu, yang melibatkan peralihan kepemilikan, benar-benar melibatkan perubahan kepemilikian dan diregister sesuai ketentuan hukum yang ada, ialah berupa "transfer of legal title," ataukah sekedar "beneficial title" atau efek terhadap keuntungan yang ditimbulkan oleh sebuah asset. ${ }^{4}$ Di samping

\footnotetext{
${ }^{3}$ BIMB berdiri pada 1 Maret 1983. Bank Islam Malaysia Berhad, Islamic Banking Practice, From Practitioner's Perspective, (Kuala Lumpur: BIMB 1994), 154.

${ }^{4}$ Nik Norzrul Thani, et.al, Law and Practice of Islamic Banking and Finance, (Malaysia: Sweet \& Maxwell Asia, 2003), 94-96. Hamzah Ismail and Radziah Abdul Latif, Survey $\mathcal{E}$ Analysis of Financial Reporting of Islamic Banks Worldwide, ( Kuala Lumpur: Arab-Malaysian Banking Group and Malaysian Accountancy Research and Education Foundation, 2001), 49. Bank Islam Malaysia Berhad, Islamic Banking Practice,162.
} 
itu semua, dikarenakan proses litigasi atas kasus-kasus dalam transaksi bisnis keuangan Islam jatuh kepada pengadilan umum (civil court), maka persyarataan sebagaimana yang ditentukan oleh syariah terkadang tidak dipertimbangkan dengan semestinya, hal ini karena pengadilan umum masih terikat dengan peraturan hukum sipil yang ada. Atas dasar itulah, maka transaksi bisnis keuangan Islam harus mempertimbangan keterkaitannya dengan keseluruhan perangkat hukum yang ada.

Perangkat syariah governance (tata kelola secara syariah) perbankan Islam di Malaysia diatur dengan berbagai aturan, baik berupa statute (undang-undang) maupun dalam bentuk peraturan lainnya semacam guidelines yang diterbitkan oleh Bank Negara Malaysia. ${ }^{5}$ Yang terpenting dalam hal ini adalah undang-undang tentang perbankan Islam (IBA 1983), misalnya dalam pasal 13A yang mengisyaratkan adanya keharusan dari bank Islam untuk mematuhi nasehat dari Shariah Advisory Council (SAC) di Bank Negara Malaysia, yang nasehat tersebut diberikan atas dasar permohonan. ${ }^{6}$ Kemudian, BAFIA 1989 juga memberikan aturan dalam tata kelola syariah ini. Pasal 124, ayat 3 dan 4 menegaskan bahwa bank atau institusi keuangan konvensional yang membuka layanan syariah dapat merefer pada Shariah Advisory Council dan harus mematuhi arahan berkenaan dengan bisnis perbankan dan keuangan berdasar perinsip syariah yang diterbikan setelah melalui konsultasi dengan SAC. ${ }^{7}$ Hal lain yang juga sangat penting bagi tata kelola syariah ini adalah aturan yang memberikan kekuatan hukum bagi keberadaan SAC, ialah adanya amandemen dari Central Bank Act 1958 (CBA). ${ }^{8}$ Dengan aturan yang terakhir ini, sangat jelas bahwa SAC memiliki otoritas atas semua bisnis keuangan syariah, termasuk asuransi, kecuali pasar modal (Securities Comission) yang memiliki penasehat syariah tersendiri dan terpisah dari bank sentral ${ }^{9}$.

\footnotetext{
${ }^{5}$ Misalnya, Guidelines Skim Perbankan Tanpa Faedah (SPTF) atau Interest Free Schemes yang diterbitkan tahun 1993, atau BNM/GPS1, Guidelines on the Governance of SharỄNah Committee for the Islamic Financial Institutions, December 2004

${ }^{6}$ Islamic Banking Act 1983 (IBA) pasal 13A.

${ }^{7}$ Banking and Financial Institutions Act 1989 (BAFIA). Pasal 124.

${ }^{8}$ Central Bank Act 1958 (CBA), pasal 16B

${ }^{9}$ Keberadaan dan keanggotaan Advisory Council untuk Securities Comission di Malaysia dapat dilihat pada, Resolutions of the Securitities Comission Shariah Advisory Council (Kuala Lumpur: Securities Commission, 2006).
} 


\section{Jurisdiksi Pengadilan Pengadilan Umum dalam Penyelesaian Sengketa}

Di Malaysia, jurisdiksi penyelesaian sengketa bisnis keuangan Islam jatuh pada pengadilan sipil atau pengadilan umum, atau yang juga disebut dengan civil court. Tentu saja yang menjadi pertanyaan adalah mengapa hal ini dapat terjadi. Jelas dipahami bahwa bisnis keuangan Islam adalah transaksi bisnis yang menggunakan prinsip-prinsip muamalah, mengapa penyelesaian sengketanya harus dilakukan di pengadilan umum, di mana hukum yang dipakai dalam pengadilan sipil adalah hukum common law warisan dari kolonial Inggris. Jawaban dari hal ini adalah berupa argumenargumen sebagaimana berikut ini:

Pertama, walaupun istilah "Islamic law" atau hukum Islam itu dicantumkan dalam peraturan hukum yang berlaku di Malaysia, ${ }^{10}$ namun harus dipahami bahwa penerapannya hanyalah terbatas pada orangorang yang memeluk agama Islam. Sehingga keberlakuan hukum Islam itu sangat terbatas. Sedangkan dalam transaksi bisnis keuangan Islam, banyak orang dari berbagai latar belakang keagamaan terlibat, bahkan jumlah non muslim relatif besar dalam komposisi pelanggan dari perbankan Islam di Malaysia.

Kedua, hal lain yang menjadi pertimbangan penting juga adalah bahwa bisnis keuangan dan perbankan diatur dalam legislasi kekuasaan federal, dan selama ini, tidak ada pengaturan tentang bisnis keuangan dan perbankan dalam legislasi di negara bagian (state). Karena itulah, negara bagian tidak dapat mengatur masalah keuangan dan perbankan, sehingga pengaturan yang bersumber pada negara (pemerintah federal) lah yang berlaku secara nasional. Sedangkan, legislasi federal (nasional) terikat dengan ketentuan bahwa bisnis keuangan dan perbankan masuk pada pengaturan hukum sipil, karenanya secara otomatis sengketa atas binis keuangan Islam ini masuk pada kewenangan pengadilan civil. Demikian pula sebaliknya, jika sengketa ini akan diselesaikan pada mahkamah syariah, haruslah dilakukan amandemen yang sangat substansial. Hal ini disebabkan karena mahkamah syariah, terutama dalam kewenangannya, diatur secara otonom oleh negara bagian. Sehingga, untuk melakukan perubahan, haruslah dilakukan amandemen melaui parlemen negara bagian di seluruh negara bagian, yang di Malaysia berjumlah 13 ditambah dengan wilayah khusus Federal Territory.

\footnotetext{
${ }^{10}$ para 1, List II dari Ninth Schedule.
} 
Di samping alasan tersebut di atas, alasan lainnya berupa putusan pengadilan. Sebagaimana yang sudah dikenal secara luas, bahwa Malaysia termasuk salah satu di antara sekian banyak negara yang menganut sistem hukum common law, atau hukum atas dasar kebiasaan. Salah satu ciri menonjol dari sistem hukum ini adalah adanya hukum berdasarkan preseden, artinya bahwa putusan pengadilan dalam suatu kasus, akan menjadi referensi sekaligus aturan yang mengikat bagi semua putusan pengadilan berikutnya yang terkait dengan masalah tersebut (the doctrine of binding precedence). Dalam konteks ini, sengketa perbankan dan bisnis keuangan Islam, kasus BIMB v Adnan bin Omar, BIMB v Tinta Press Sdn. Bhd. E Ors, juga kasus Dato' Nik Mahmud v BIMB, serta kasus Bank Rakyat $v$ Emcee Corp, Affin Bank v Zulkifli, etc, menjadi preseden yang mengikat, dimana dalam kasus tersebut juga diputuskan bahwa penyelesaian kasuskasus sengketa bisnis keuangan Islam jatuh pada kewenangan pengadilan sipil, dan bukannya mahkamah syariah.

\section{Analisis Kasus Sengketa Perbankan Islam di Malaysia}

Dari evaluasi terhadap kasus-kasus yang diputuskan oleh pengadilan terkait dengan penyelesaian sengketa bisnis keuangan Islam, khususnya adalah perbankan Islam, putusan dapat dikategorikan dalam dua macam. Pertama, kasus-kasus di mana pengadilan menerapkan atau memberlakukan dokumen tentang bisnis keuangan Islam yang telah disepakati dalam kontrak di antara pihak-pihak terkait. Kedua, kasuskasus di mana pengadilan telah menempuh pendekatan dengan menyamakan kasus sengketa bisnis keuangan Islam dengan kasus perbankan konvensional.

Untuk lebih jelas memahami kedua kategori tersebut, penting untuk dilihat beberapa prinsip utama yang dapat disimpulkan dari berbagai putusan pengadilan dalam menyelesaikan sengketa bisnis keuangan Islam.

Pertama, kasus Bank Islam Malaysia Berhad v Adnan bin Omar (1994). ${ }^{11}$ Dari kassus ini dapat dilihat dengan jelas, prinsip pokok yang dapat di simpulkan adalah bahwa pengadilan mengakui kontrak Bai Bithaman Ajil (BBA) yang dilakukan oleh para pihak. Artinya, bahwa kontrak BBA tersebut memang sebuah kontrak tersendiri, meskipun jenis

${ }^{11}$ Bank Islam Malaysia Berhad v Adnan bin Omar dalam All Malaysia Reports (1994) (3). 
kontrak tersebut relatif baru dibandingkan kontrak yang pada umumnya diterapkan pada perbankan konvensional. Namun, meski kontrak tersebut diakui sebagai bentuk kontrak yang sah dan mengikat, pengadilan berpendapat bahwa niat dari para pihak dalam melakukan perjanjian tersebut adalah untuk memberikan dan mendapatkan pinjaman uang (hutang), dan bukannya untuk berjual beli dalam arti yang sebenarnya. Di samping itu, pengadilan juga tidak mempertanyakan hal-hal terkait dengan interest (bunga).

Kasus kedua yang cukup monumental bagi penyelesaian sengketa bisnis keuangan Islam adalah kasus Datuk Haji Nik Mahmud bin Daud v Bank Islam Malaysia Bhd (1994). ${ }^{12}$ Pertama, mahkamah agung (high court) dalam putusannya menerima bahwa kontrak BBA terdiri dari Property Purchase Agreement dan Property Sale Agreement. Kedua kontrak tersebut merupakan bagian dari rangkaian tindakan yang harus dilakukan bagi transaksi dengan skim BBA. Dengan kata lain, partikularitas dari perbankan Islam yang muncul dalam bentuk kontrak yang ganda ini, dapat diterima oleh pengadilan.

Kasus ketiga yang layak dipertimbangkan bagi pattern dalam penyelesaian sengketa perbankan Islam adalah kasus Bank Kerjasama Rakyat Masia Bhd v Emcee Corporation Sdn Bhd (2003). ${ }^{13}$ Pengadilan banding mengakui bahwa fasilitas pembiayaan melalui BBA disahkan dengan dua pejanjian, ialah PPA dan PSA. Masing-masing pihak terikat dengan kedua perjanjian yang telah disepakatinya. Lain dari pada itu, pengadilan juga berpendapat bahwa dengan membayar sebagian dari cicilan -belum keseluruhannya- seorang nasabah dianggap sebagai wanprestasi (default). Sebagai akibatnya, pihak bank, tidak memiliki hak untuk mencairkan pembiayaan yang tersisa dalam skim tersebut.

Kasus keempat, dan yang putusannya di pengadilan dinilai cukup kontroversial adalah kasus Affin Bank Bhd v Zulkifli Abdullah (2006). ${ }^{14}$ Prinsipprinsip yang dapat disimpulkan dari putusan pengadilan adalah bahwa nasabah, yang dalam hal ini sebagai terdakwa, wanprestasi (default) dalam skim pembiayaan melalui kontrak BBA. Kewajiban dari nasabah, dalam

\footnotetext{
${ }^{12}$ Datuk Haji Nik Mahmud bin Daud v Bank Islam Malaysia Bhd, Malaysian Law Journal (1996) (4).

${ }^{13}$ Bank Kerjasama Rakyat M'sia Bhd v Emcee Corporation Sdn Bhd, Malaysian Law Journal (2003) (2)

${ }^{14}$ Affin Bank Bhd v Zulkifli Abdullah, Current Law Journal (2006) (1)
} 
hal ini adalah untuk membayar keseluruhan harga jual, tidak ditunaikan dengan semestinya sesuai dengan kontrak yang telah disepakati. Pendapat pengadilan yang dapat dikatakan cukup mencengangkan adalah, bahwa pihak bank seharusnya tidak mengklaim keseluruhan jumlah harga jual, mengingat bahwa keseluruhan harga tersebut merupakan keuntungan yang didapat tanpa upaya (unearned profit), melainkan hanya jumlah pembayaran sampai dengan skim tersebut dihentikan oleh bank dan dilakukannya eksekusi atas asset jaminan. Pengadilan juga menolak aturan yang dipakai bahwa ibra' adalah diskresi yang secara sepihak dapat ditentukan oleh pihak bank. ${ }^{15}$ Lebih dari itu, bank tidak setuju dengan argumen yang menyatakan bahwa SAC harus dirujuk dalam masalah ini, dan sebaliknya bank menyatakan bahwa bahwa pengadilan lah yang memutuskan hal ini.

Kasus terakhir yang cukup memicu kontroversi dalam masalah penyelesaian sengketa tentang bisnis keuangan Islam adalah kasus $\mathrm{Ma}$ layan Banking Bhd v Marilyn Ho Siok Lin (2006). ${ }^{16}$ Pengadilan, dalam mengadili hal ini merujuk pada kasus Affin Bank Bhd v Zulkifli Abdullah (2006). Pengadian menerima keharusan untuk merujuk kasus tersebut dikarenakan doktrin atas "the binding precedence" dalam sistem common law. Yang cukup menarik adalah bahwa pengadilan memberikan penilaian bahwa nasabah bank seharusnya tidak diletakkan dalam posisi yang lebih merugikan dibandingkan jika transaksi pembiayaan dilakukan dalam perbankan konvensional. Sehingga, pengadilan menyatakan bahwa bank telah bertindak eksploitatif dan merugikan nasabah, melebihi dari apa yang terjadi dalam sistem konvensional.

Dari berbagai permasalahan dan putusan-putusan yang ada tersebut, ada beberapa hal yang harus dilakukan. Di antara yang terpenting adalah amandemen terhadap aturan hukum yang ada, termasuk amandemen terhadap undang-undang dasar (Federal Constitution), utamanya dalam hal terkait dengan berbagai aspek keberlakuan hukum Islam. Di samping itu, haruslah dilakukan berbagai upaya yang serius untuk meningkatkan dan memperbaiki dokumen transaksi (kontrak) agar lebih shariah compliant (patuh syariah), bukan hanya sebagai formalitas yang mengabaikan nilainilai dasar dari prinsip-prinsip Islam. Terakhir, memberikan training bagi

${ }^{15} \mathrm{Ibra}^{\prime}$ adalah pembebasan atas seseorang atas hutang. Lihat pada, Resolutions of the Securitities Comission Shariah Advisory Council (Kuala Lumpur: Securities Commission, 2006), 46.

${ }^{16}$ Malayan Banking Bhd v Marilyn Ho Siok Lin, Malayan Law Journal (2006) (7) 
para hakim dan praktisi hukum lainnya agar memahami dengan baik tentang bisnis keuangan Islam, sehingga tidak disalahmengertikan dengan sistem bisnis keuangan konvensional.

Sedangkan yang diperlukan di masa mendatang adalah, pertama, haruslah dibangun dan dikembangkan perangkat hukum yang lebih kondusive dan kuat. Kemudian, diupayakan agar mekanisme penyelesaian sengketa dapat dilakukan dengan lebih baik, baik dari sisi prosedur maupun substansi hukum yang mengaturnya, sehingga baik sejak dari praktik pelaksanaan kontrak hingga penyelesaian sengketanya benar-benar patuh syariah. Selanjutnya, transaksi dalam bisnis keuangan Islam harus dilakukan secara transparan, (disclosure, accounting $\mathcal{E}$ auditing). Dan yang tidak kalah pentingnya adalah terciptanya produk-produk perbankan Islam yang competitif, efisien, serta, mendapat pengakuan dan penerimaan secara global.

\section{Penyelesaian Sengketa Bisnis Keuangan Syariah di Indonesia}

Hingga saat ini, perbankan syariah di Indonesia telah berusia 15 tahun. Hal ini dilihat dari berdirinya bank syariah pertama pada tahun 1991 dan mulai beroperasi tahun 1992, ialah Bank Muamalat Indonesia (BMI). ${ }^{17}$ Memang harus diakui, bahwa perkembangan bisnis keuangan syariah di Indonesia tidak sebaik dari yang dialami Malaysia, namun, hari ini dapat dilihat bahwa perkembangan bisnis ini juga sudah menunjukkan eksistensinya. Hal ini dibuktikan dengan bermunculannya berbagai institusi keuangan yang menggunakan prinsip syariah dalam pelayanannya yang mencapai jumlah sebagaimana dikemukakan di awal artikel ini.

Salah satu faktor yang menjadikan perkembangan bank syariah di Indonesia relatif lambat, terutama jika dibandingkan dengan Malaysia, adalah faktor hukum. Hal ini Nampak dari fakta bahwa tertundanya operasi dari BMI sendiri, yang sebenarnya sudah berdiri pada tahun 1991, baru dapat beroperasi pada tahun 1992 setelah terbitnya Undang-Undang no 7 tahun 1992 tentang Perbankan. ${ }^{18}$ Artinya sejak awal dari inisiasi

${ }^{17}$ Sinansari Ecip, Syu'bah Asa and Evesina, Ketika Bagi Hasil Tiba, Perjalanan 10 Tahun BankMuamalat (Jakarta: Muamalat Institute, 2002), xiv-xvi. Adiwarman A. Karim, "Para Pejuang Ekonomi Syariah", Republika, 23 Mei 2005. Muhammad Syafi'i Antonio. Bank Syariah dari Teori ke Praktik. (Jakarta: Gema Insani Press, Jakarta: 2001), 25.

${ }^{18}$ Undang-Undang no 7 tahun 1992 tentang Perbankan ini merupakan pengganti dari Undang-Undang no 14 tahun 1967 tentang Prinsip-Prinsip Perbankan. 
untuk mendirikan dan mengembangan institusi perbankan syariah, kendala hukum sudah dihadapi. Dalam tahap selanjutnya, dalam penyelesaian sengketa yang muncul, satu-satunya metode adalah arbitrase yang diberikan kewenangannya dibawah Badan Arbitrase Syariah Nasional (Basyarnas). ${ }^{19}$

Ini berarti, bahwa penyelesaian sengketa melalui pengadilan tidak dimungkinkan dalam kasus-kasus sengketa yang muncul dari transaksi bisnis keuangan Islam. Dengan kata lain, pilihan penyelesaian sengketa menjadi tidak ada. Dari sisi ini saja, jelas bahwa perbankan syariah kurang mendapat dukungan yang memadahi dari perangkat hukum, sesuatu yang menjadi salah satu nadi dari perkembangan industri keuangan berbasis syariah.

Meski pada tahun 1998 undang-undang tentang Perbankan diamandemen, sehingga lahirlah kemudian UU no 10 tahun 1998 tentang Perbankan, dan di dalamnya sistem perbankan syariah mendapat pengakuan yang lebih memadahi, jauh daripada yang diberikan oleh UU no. 71992 tentang Perbankan. ${ }^{20}$ Akan tetapi tetap saja, masalah penyelesaian sengketa belum mendapatkan kejelasan dari undangundang. Dengan kata lain, amandemen tetap tidak memberikan efek terhadap metode penyelesaian sengketa.

${ }^{19}$ Di Indonesia, arbitrase syariah didirikan bersamaan dengan pendirian Bank Muamalat Indonesia (BMI) tahun 1992. Tujuannya untuk menangani sengketa antara nasabah dan bank syariah pertama tersebut. Lembaga arbitrase tersebut dikenal dengan Badan Arbitrase Arbitrase Muamalat (BAMUI) berdasarkan SK No Kep-392/ MUI/V / 1992. Pada tahun 2003, beberapa bank atau Unit Usaha Syariah (UUS) lahir sehingga BAMUI dirubah menjadi Badan Arbitrase Syariah Nasional (Basyarnas) hingga kini. Perubahan tersebut berdasarkan SK MUI No Kep-09/MUI XII/2003 tertanggal 24 Desember 2003. "Ada Apa dengan Badan Arbitrase Syariah?" dalam www.hukumonline.com diakses pada 30 November 2007.

${ }^{20}$ Pengakuan yang lebih jelas dari undang-undang yang baru ini adalah pada adanya ketentuan tentang jenis usaha dari perbankan syraiah, termasuk berbagai produk yang ditawarkannya. Jauh dari undang-undang sebelumnya yang hanya 'sekedar membuka peluang' bahwa perbankan non bunga dapat beroperasi di Indonesia. Ini dapat dilihat pada pasal 1 ayat 12 dari UU no. 7 tahun 1992 yang berbunyi: "Kredit adalah penyediaan uang atau tagihan yang dapat dipersamakan dengan itu, berdasarkan persetujuan atau kesepakatan pinjam-meminjam antara bank dengan pihak lain yang mewajibkan pihak peminjam untuk melunasi hutangnya setelah jangka waktu tertentu dengan jumlah bunga, imbalan atau pembagian hasil keuntungan;" 


\section{Dasar Penyelesaian Sengketa Melalui Basyarnas}

Penyelesaian melalui arbitrase, didasarkan pada inisiatif Majelis Ulama Indonesia dengan Bank Indonesia. Sehingga dalam Peraturan Bank Indonesia maupun fatwa dari Dewan Syariah Indonesia (DSN), selalu disebutkan bahwa jika terjadi kasus sengketa dalam bisnis keuangan syariah, maka penyelesaiannya melalui Basyarnas. ${ }^{21}$ Sehingga atas dasar itu, kemudian memang, beberapa kasus diajukan ke Basyarnas. Meski sementara ini performa Basyarnas masih perlu banyak dibenahi, namun dalam kurun yang cukup lama Basyarnas telah berperan sebagai satusatunya lembaga yang berwenang menyelesaikan sengketa dalam hal ini.

Keberadaan Basyarnas yang tidak didukung secara memadahi oleh perangkat hukum telah menjadikan institusi ini sekan kurang berwibawa, dan dalam tingkat tertentu telah memberikan kontribusi bagi imej bahwa pemerintah tidak serius dalam mengembangkan bisnis keuangan syariah.

Dalam perkembangan selanjutnya, harus diakui bahwa tidak semua pihak yang bersengketa bersedia untuk membawa penyelesaian kasusnya ke lembaga arbitrase. Kelemahan utama arbitrase adalah bahwa suatu sengketa untuk dapat dibawa pada penyelesaian hanya jika para pihak rela dan bersedia untuk datang bersama dan mempercayakan lembaga arbitrase untuk menyelesaikannya. Sehingga, dalam kasus di mana salah satu pihak diperkirakan akan rugi, maka pihak yang merasa akan dirugikan tersebut cenderung tidak bersedia jika kasusnya diselesaikan melalui lembaga arbitrase tersebut. Kasus ini, meski tidak diungkap dengan identitas yang jelas, telah terjadi di Indonesia. ${ }^{22}$ Fakta ini telah

${ }^{21}$ Dalam setiap fatwa dari DSN serta sebagian besar Peraturan Bank Indonesia terkait dengan produk, selalu menyebutkan bahwa jika terjadi sengketa terkait dengan transaksi produk perbankan syariah, maka setelah penyelesaian secara musyawarah gagal, maka dibawa ke Basyarnas. Lihat, Himpunan Fatwa Dewan Syariah Nasional MUI (Jakarta: Dewan Syariah Nasional MUI \& Bank Indoneisa, 2006), juga, PBI no. 7/46/PBI/ 2005 tentang Akad Penghimpunan dan Penyaluran Dana bagi Bank yang melaksanakan Kegiatan Usaha Berasarkan Prinsip Syariah, pasal 20 ayat 1 dan 2.

${ }^{22}$ Kasus sengketa dantara Pertamina dengan dua bank syariah untuk transaksi murabahah pengadaan kendaraan 100 unit, dan masing-masing bank syariah 50 unit. Satu kali Pertamina terlambat membayar, dan kemudian secara sepihak salah satu bank syariah menaikkan harga jual dalam akad murabahah secara sepihak. Maka, kasus sengketa pun merebak. Namun, kasus ini tidak terselesaikan dikarenakan pihak bank tidak mau membawa ini ke Basyarnas. "Penyelesaian Sengketa Bank Syariah Masih Diperdebatkan," diakses dari www.hukumonline.com pada 18 Juli 2008. 
dengan jelas menunjukkan kelemahan lembaga arbitrase syariah yang ada dan berwenang.

\section{Penyelesaian Sengketa Transaksi Keuangan Syariah Melalui Pengadilan}

Dengan melihat kelemahan lembaga arbitrase di atas, dan juga untuk menjaga kepercayaan publik dan masyarakat dunia yang berkepentingan dengan bisnis keuangan syariah di Indonesia, bagaimanapun juga, kesempatan untuk penyelesaian melalui pengadilan harus dibuka. Keinginan yang semacam ini barulah mendapatkan jawabannya dalam dua tahun terakhir ini. Pada tahun 2006, penyelesaian sengketa baru mendapatkan titik terang dengan adanya amandemen dari Undang Undang no. 7 tahun 1989 menjadi Undang Undang no. 3 tahun 2006 tentang Peradilan Agama. Di mana dalam pasal 49 dari undang-undang tersebut disebutkan :"Pengadilan agama bertugas dan berwenang memeriksa, memutus, dan menyelesaikan perkara di tingkat pertama antara orang-orang yang beragama Islam di bidang: a. perkawinan; b. waris; c. wasiat; d. hibah; e. wakaf; f. zakat;g. infaq;h. shadaqah; dan i. ekonomi syari'ah." 23

Untuk keperluan itu, Mahkamah Agung kemudian menyiapkan berbagai perangkat yang diperlukan agar pengadilan agama siap untuk menangani sengketa keuangan syariah. Termasuk di antara persiapan yang sedang dilakukan saat ini adalah penyusunan naskah kompilasi hukum perdata Islam yang kelak akan digunakan sebagai referensi dalam memutus kasus-kasus sengketa terkait dengan bisnis keuangan syariah. Kompilasi ini dinamai dengan Kompilasi Hukum Ekonomi Syariah $(\mathrm{KHES}){ }^{24}$

Namun, permasalahan yang kemudian muncul adalah adanya UU Perbankan Syariah yang telah disetujui oleh Dewan Perwakilan Rakyat (DPR) telah memberikan pernyataan yang nampak bertentangan dengan UU tentang Peradilan Agama tersebut di atas. ${ }^{25}$ Pernyataan dimaksud

\footnotetext{
${ }^{23}$ Undang-Undang Republik Indonsia Nomor 3 tahun 2006 tentang Perubahan atas Undang-Undang no. 7 Tahun 1989 tentang Peradilan Agama.Pasal 49.

${ }^{24}$ www.badilag.net, diakses 19 Juli 2008

${ }^{25}$ Sampai dengan saat artikel ini ditulis, 20 Juli 2008, RUU Perbankan Syariah yang telah disyahkan oleh DPR belum diundangkan atau diterbitkan dalam lembaran Negara.
} 
adalah bahwa penyelesaiakan sengketa kasus bisnis keuangan syariah bersipat optional, dalam artian bahwa penyelesaian sengketanya dalam diputuskan oleh Pengadialan Agama (PA) maupun Pengadilan Umum (PU). Sehingga, PA bukan satu-satunya lembaga peradilan yang memiliki kewenangan untuk menangani dan memutuskan kasus tersebut. ${ }^{26}$

Tentu saja, tidak harmonisnya antara dua undang-undang tersebut menyisakan permasalahan tersendiri. Meski demikian, barangkali, dalam hal singkronisasi hukum dapat dinilai tidak bermasalah dikarenakan kedua aturan hukum tersebut dapat dipahami sebagai tidak bertentangan. Artinya bahwa UU Perbankan Syariah tidak menfikan kewenangan dari Pengadilan Agama untuk menangani sengketa bisnis keuangan syariah, sebagaimana undang-undang Pengadilan Agama juga tidak memberikan restriksi bahwa pengadilan diluar pengadilan agama tidak berwenang menangani penyelesaian sengketa bisnis keuangan syariah. Namun, dalam hal pengembangan kelembagaan hal ini dapat menimbulkan masalah yang tidak sederhana.

Permasalahan di seputar penanganan sengketa bisnis keuangan Islam melalui pengadilan, sebagaimana yang juga nampak dari pengalaman Malaysia di muka, bukanlah hal yang sederhana. Hal ini disebabkan karena transaksi keuangan Islam atau syariah adalah suatu hal yang baru, yang dapat dikatakan tidak dikenal dalam nomenklatur hukum bisnis modern yang hampir sepenuhnya dikembangkan dari sistem hukum barat, terutama di negara berkembang yang mengalami masa penjajahan oleh kolonial Barat. Sehingga dengan kata lain dapat disebutkan bahwa untuk menangani sengketa bisnis keuangan semacam ini memerlukan pemahaman atas hal baru yang tidak sederhana untuk ditempuh, terlebih kemudian diadopsi dalam sebuah sistem peradilan. Di amping itu, dilihat dari sifat bahwa berbagai ketentuan terkait dengan bisnis keuangan syariah adalah bagian dari hukum muamalah, sehingga Pengadilan Agama sudah lebih akrab dengan isu-isu di seputar muamalah dibandingkan Pengadilan Umum.

Karena itulah, dibukanya pintu penyelesaian sengketa bisnis ini secara litigatif, mengharuskan adanya reformasi atau paling tidak restrukturisasi dalam berbagai lembaga yang terkait. Sebenarnya, dengan menunjuk salah

${ }^{26}$ "Sengketa Perbankan Syariah Ditangani Secara Optional," diakses dari, http:/ /www.ekonomisyariah.net/ , pada 18 Juli 2008 
satu peradilan untuk menangani sengketa ini jauh lebih realistis daripada melepaskan dalam opsi yang sepenuhnya menjadi hak para pihak untuk memilihnya. Mengapa demikian, karena melakukan pembenahan dalam satu jenis peradilan, misalnya adalah Pengadilan Agama, akan jauh lebih feasible dari pada menyiapkan berbagai sistem peradilan.

Di Malaysia misalnya, yang memberikan kewenangan pada Pengadilan Umum (civil court) pada akhirnya harus membuat satu divisi khusus yang menangani kasus sengketa bisnis keuangan Islam. Dengan pembentukan itupun tidak lantas menyelesaikan masalah. Kerangka befikir (mindset) para hakim yang telah dididik dan bekerja dalam sistem hukum sipil dalam waktu yang cukup lama, telah menjadikan mereka melihat kasus transaksi keuangan Islam, yang sepenuhnya dikendalikan oleh hukum muamalah, dengan kacamata hukum sipil, karenanya, sebagaimana disebutkan dalam pembahasan di depan, transaksi BBA akhirnya dinilai sebagai loan contract, dan bukannya sale contract.

Memang, peningkatan dari aspek sumber daya manusia dapat diupayakan melalui serangkaian training dan shortcourse, namun pertautan berbagai prinsip dalam muamalah adalah hal yang memerlukan pemahaman lebih mendalam daripada upaya yang sifatnya ad-hoc. Lain masalahnya jika kemudian dilakukan rekruitmen sumberdaya manusia baru yang memang memiliki kecakapan dalam bidang terkait.

Sehingga, sebenarnya, memberikan opsi bebas sebagaimana yang disebutkan dalam RUU Perbankan Syariah, adalah sebuah putusan yang sangat berresiko. Adalah sangat baik jika memang keseluruhan peradilan yang memungkinkan untuk dijadikan pilihan tempat penyelesaian sengketa kemudian dapat ditingkatkan untuk sampai pada tahap kesiapan menyelesaiakan kasus-kasus semacam ini, namun jika justeru karena banyaknya peradilan sehingga persiapan hanya setengah hati, hal ini justeru akan menjadi masalah.

Mengapa penyiapan penting? Salah satu fitur yang nampak dalam perkembangan transaksi keuangan syariah (Islam) adalah bersifat relatif global. Kebanyakan investasi syariah datang dari Timur Tengah yang kaya akan minyak. ${ }^{27}$ Overliquiditas karena ptrol windfall menjadikan aliran dana dari Timur Tengah ke Asia Tenggara cukup besar. Ini artinya bahwa banyak kasus yang dapat dikatakan sebagai kasus internasional dikarekan para pihak yang terlibat dapat berasal dari luar negeri. Kasus sengketa

27 "Shariah Wave" dalam, Asiamoney, vol. XVII, May 2006, 42-44 
bisnis keuangan Islam yang melibatkan Beximco Pharmaceuticals Ltd v Shamil Bank of Bahrain adalah kasus yang nampak. ${ }^{28}$ Para pihak, yang mereka berasal dari Bahrain dan Bangladesh, saling tunduk pada aturan Negara yang berbeda antara satu dengan lainnya, sepakat dalam perjanjian yang ditandatanganinya bahwa jika terjadi sengketa di kemudian hari atas transaksi tersebut, maka Pengadilan London di Inggris yang akan menyelesaikannya.

Dalam kenyataan, tidaklah mudah bagi Pengadilan di London untuk menyelesaikan masalah tersebut, dikarenakan, Inggris yang bukan Negara Islam dan hukum yang berlaku adalah common law, harus mengadili transaksi bisnis keuangan Islam yang mendasarkan aturannya pada ajaran Islam. Meski pada akhirnya pengadilan memenangkan pihak Shamil Bank yang bermarkas di Bahrain, namun bagaimana hakim harus 'berjuang' untuk sampai pada putusan yang mempertimbangkan aspek ajaran Islam, merupakan pelajaran yang penting untuk dipertimbangkan.

\section{Penutup}

Malaysia, yang telah menangani penyelesaian sengketa bisnis keuangan Islam sejak tahun tahun awal dari perkembangan perbankan Islam di negara tersebut, telah memiliki pengalaman sekitar 25 tahun. Hal-hal yang perlu dilakukan bagi Indonesia yang masih dalam tahap mempersiapkan pengadilan dalam menangani atau menyelesaikan kasuskasus sengketa bisnis keuangan syariah adalah mengambil beberapa pelajaran yang dipandang relevan. Bahwa, kerumitan sengketa bisnis keuangan syariah haruslah diantisipasi dengan mendidik pada hakim agar memahami berbagai aspek hukum terkait dengan bisnis tersebut. Di sisi lain, rekruitmen hakim baru yang masih fresh juga diperlukan untuk memberikan kualifikasi yang proporsional terhadap kemampuan bidang bisnis keuangan syariah ini. Harus diingat juga, bahwa asingnya berbagai ketentuan dalam transaksi keuangan syariah ini bagi Pengadilan Umum, adalah sebuah tambahan masalah yang tidak sederhana. Bahkan jika dimungkinkan, harus ada divisi khusus di pengadilan umum jika memang pengadilan umum juga diberikan kewenangan untuk menanganinya.

${ }^{28}$ Beximco Pharmaceuticals Ltd v Shamil Bank of Bahrain EC [2004] APP.L.R. diakses dari http://www.nadr.co.uk/articles/published/ArbitLawReports/ Beximco\%20v\%20Shamil\%202004.pdf. Pada 18 Juli 2008 


\section{Daftar Pustaka}

Buku \& Jurnal

Antonio, Muhammad Syafi'I, Bank Syariah dari Teori ke Praktik. Jakarta: Gema Insani Press, 2001

Bank Islam Malaysia Berhad, Islamic Banking Practice, From Practitioner's Perspective, Kuala Lumpur: BIMB, 1994

Ecip, Sinansari, Syu'bah Asa dan Evesina, Ketika Bagi Hasil Tiba, Perjalanan 10 Tahun BankMuamalat, Jakarta: Muamalat Institute, 2002

Federal Constitution of Malaysia

Himpunan Fatwa Dewan Syariah Nasional MUI, Jakarta: Dewan Syariah Nasional MUI \& Bank Indoneisa, 2006

Ismail, Hamzah and Radziah Abdul Latif, Survey $\mathcal{E}$ Analysis of Financial Reporting of Islamic Banks Worldwide, Kuala Lumpur: Arab-Malaysian Banking Group and Malaysian Accountancy Research and Education Foundation, 2001

Karim, Adiwarman A, "Para Pejuang Ekonomi Syariah", Republika, 23 Mei 2005.

Thani, Nik Norzrul, et.al, Law and Practice of Islamic Banking and Finance, (Malaysia: Sweet \& Maxwell Asia, 2003)

Resolutions of the Securitities Comission Shariah Advisory Council, Kuala Lumpur: Securities Commission, 2006.

Asiamoney, vol. XVII, May 2006

Data Elektronik

Bank Negara Malaysia, http//:www.bnm.gov.my, diakses pada 16 Juli 2008

Bank Negara Indonesia, http//:www.bi.go.id, diakses pada 16 Juli 2008

Direktorat Jenderal Peradilan Agama, dalam, www.badilag.net, diakses pada 19 Juli 2008

"Ada Apa dengan Badan Arbitrase Syariah?" dalam www.hukumonline.com, diakses pada 30 November 2007

"Penyelesaian Sengketa Bank Syariah Masih Diperdebatkan," dalam, www.hukumonline.com, diakses pada 18 Juli 2008

"Sengketa Perbankan Syariah Ditangani Secara Optional," dalam, www.ekonomisyariah.net, diakses pada 18 Juli 2008

Produk Hukum dan Kasus 
Banking and Financial Institutions Act 1989 (BAFIA)

BNM/GPS1 Guidelines on the Governance of Shariah Committee for the Islamic Financial Institutions 2004

BNM Guidelines Skim Perbankan Tanpa Faedah (SPTF) 1993

Central Bank Act 1958 (CBA)

Islamic Banking Act 1983 (IBA)

PBI no. 7/46/PBI/2005 tentang Akad Penghimpunan dan Penyaluran Dana bagi Bank yang melaksanakan Kegiatan Usaha Berasarkan Prinsip Syariah.

Undang-Undang no 7 tahun 1992

Undang-Undang Republik Indonsia Nomor 3 tahun 2006 tentang Perubahan atas Undang-Undang no. 7 Tahun 1989 tentang Peradilan Agama.

Bank Islam Malaysia Berhad v Adnan bin Omar dalam All Malaysia Reports (1994) (3).

Datuk Haji Nik Mahmud bin Daud v Bank Islam Malaysia Bhd, Malaysian Law Journal (1996) (4).

Bank Kerjasama Rakyat M'sia Bhd v Emcee Corporation Sdn Bhd, Malaysian Law Journal (2003) (2).

Affin Bank Bhd v Zulkifli Abdullah, Current Law Journal (2006) (1)

Malayan Banking Bhd v Marilyn Ho Siok Lin, Malayan Law Journal (2006) (7)

Beximco Pharmaceuticals Ltd v Shamil Bank of Bahrain EC [2004] APP.L.R. 